\title{
Diffuse intestinal nodular lymphoid hyperplasia in an immunoglobulin-A-deficient patient with Helicobacter pylori infection
}
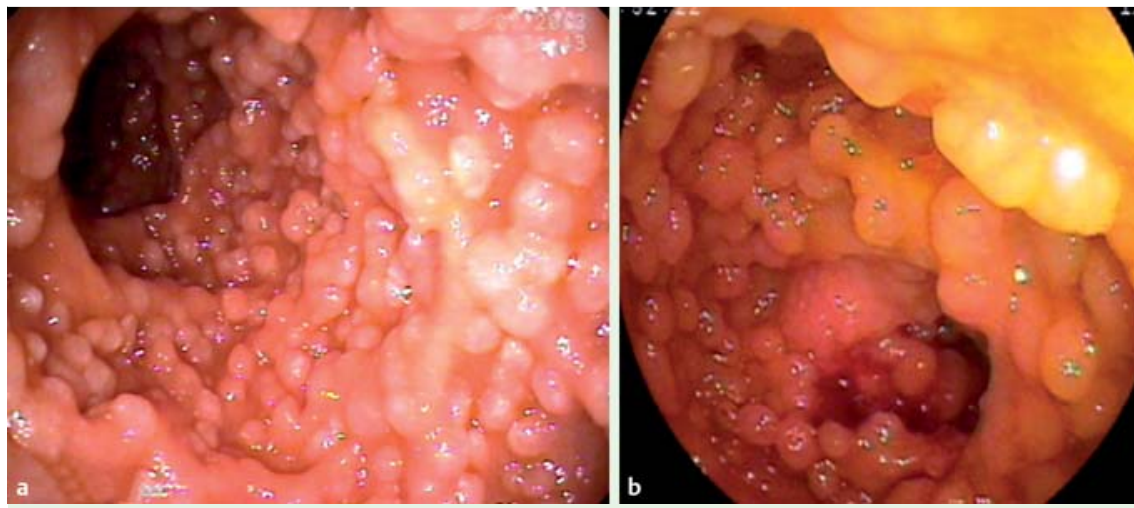

Fig. 1 a, b Endoscopic appearance of second part of the duodenum: a multiple polypoid lesions $3-5 \mathrm{~mm}$ in size throughout the duodenum; $\mathbf{b}$ terminal ileum.

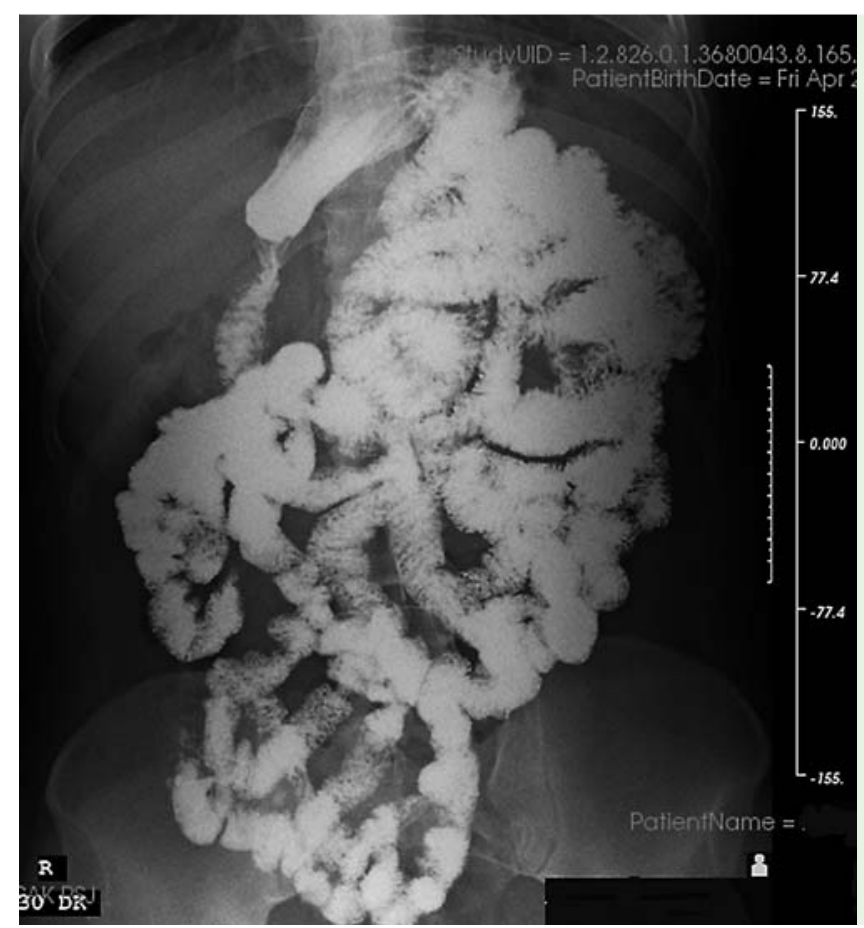

Fig. 2 Small-bowel series revealed numerous nodular filling defects throughout the small bowel.

A 34-year-old man was admitted to hospital complaining of epigastric pain and chronic diarrhea without blood or mucus. He had no weight loss. His hematologic, biochemical, and serologic tests and stool examination showed normal results, but his levels of immunoglobulin A (IgA) were under the lower limit. Endoscopic examination revealed multiple millimetric polypoid lesions throughout the duodenum and terminal ileum ( $\bullet$ Fig. 1). His-

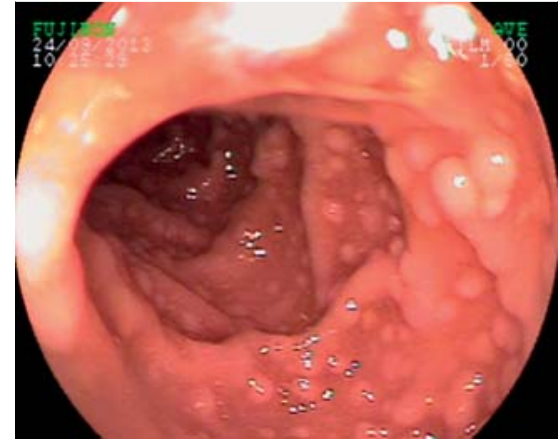

Fig. 3 Duodenum in posttreatment period: nodules have decreased in size and number.

end of the eradication therapy, $\mathrm{C}_{14}$ urea breath test gave a negative result. At follow-up endoscopy, the duodenal nodules had regressed ( $\bullet$ Fig.3). The patient was referred to an immunologist for further investigation.

Nodular lymphoid hyperplasia (NLH) of the gastrointestinal tract is a rare pathology in adults. It is characterized by the presence of numerous visible mucosal nodules measuring up to $5 \mathrm{~mm}$ in diameter. Histologically, hyperplastic lymphoid follicles with large germinal centers are seen in the lamina propria and superficial submucosa. The etiology is unknown. Viral agents, giardiasis, and common variable immunodeficiency have been suggested to be associated with NLH [1]. The association of NLH with $H$. pylori and IgA deficiency has been rarely described in the literature [2,3]. Treatment of the $H$. pylori infection can provide regression of nodules. However, treatment of all infections is very difficult, and infections tend to be more persistent in patients with immune deficiencies. Endoscopists should consider the possibility of IgA deficiency in patients who present with diffuse nodular lesions in the small bowel, and $H$. pylori infection should be tested for and, if found, treated with an appropriate drug regimen.

Endoscopy_UCTN_Code_CCL_1AB_2AZ_3AC

\section{Competing interests: None}


Sebahat Basyigit', Bora Aktas', Huyla Simsek ${ }^{2}$, Metin Kucukazman ${ }^{1}$

${ }^{1}$ Department of Gastroenterology, Kecioren Research and Training Hospital, Ankara, Turkey

${ }^{2}$ Department of Pathology, Kecioren Research and Training Hospital, Ankara, Turkey

\section{References}

1 Rubio-Tapia A, Hernández-Calleros J, Trinidad-Hernández $S$ et al. Clinical characteristics of a group of adults with nodular lymphoid hyperplasia: a single center experience. World J Gastroenterol 2006; 12: 1945

2 Khuroo MS, Khuroo NS, Khuroo MS. Diffuse duodenal nodular lymphoid hyperplasia: a large cohort of patients etiologically related to Helicobacter pylori infection. BMC Gastroenterol 2011; 11: 36

3 Postgate A, Despott E, Talbot I et al. An unusual cause of diarrhea: diffuse intestinal nodular lymphoid hyperplasia in association with selective immunoglobulin A deficiency (with video). Gastrointest Endosc 2009; 70: $168-169$

\section{Bibliography}

Dol http://dx.doi.org/ 10.1055/s-0034-1377938

Endoscopy 2014; 46: E568-E569

(c) Georg Thieme Verlag KG

Stuttgart · New York

ISSN 0013-726X

\section{Corresponding author}

Sebahat Basyigit, MD

Department of Gastroenterology Kecioren Research and Training Hospital Pınarbaşı Mah. Sanatoryum Cad.

Ardahan Sok. No: 25

06380 Keciören

Ankara

Turkey

Fax: +90-312-3569003

sbuyuktemiz@yahoo.com 